\title{
Differential systemic MyD88-dependent versus MyD88- independent cytokine ratio by etiologic agent in adults with severe community-acquired pneumonia
}

\author{
Dean Campbell and Mark J. Cowan* \\ *Correspondence: mark.cowan@va.gov \\ CrossMark \\ \& Click for updates
}

Department of Medicine, Division of Pulmonary and Critical Care Medicine, The University of Maryland School of Medicine, Baltimore, USA.

\begin{abstract}
Purpose: Classifying bacteria early, before cultures results are available, would improve the choice of initial antibiotics in patients with severe pneumonia. TLR2 and TLR4 transduce signal through the MyD88dependent pathway to stimulate IL-8 and TNF- $\alpha$ production. TLR4 can also signal through a MyD88independent pathway to stimulate RANTES and IFN- $\beta$ production. As gram-negative bacteria primarily activate TLR4, while gram-positive bacteria also activate TLR2, differential cytokine expression would be expected depending on specific bacterial etiologies.

Methods: Admission serum samples from 53 patients admitted to the Medical Intensive Care Unit at the University of Maryland Medical Center between January 2006 and September 2013 were assayed for IL-8, RANTES, TNF- $\alpha$, and IFN- $\beta$ levels using the University of Maryland cytokine core laboratory and commercial ELISA kits. Cytokine levels and the ratio of MyD88-independent to MyD88-dependent cytokines, $([\mathrm{IFN}-\alpha] \mathrm{X} \sqsubset \mathrm{RANTES}]) /([\mathrm{IL} 8] \mathrm{X}[\mathrm{TNF}-\alpha])$ were compared to the culture identified organisms.

Results: 14 gram-negative and 17 gram-positive pneumonias were identified. None of the individual cytokine demonstrated statistically significant differences between the gram-negative and gram-positive infections. The ratio of MyD88-independent/MyD88-dependent cytokines was 111.1 34.9 in gram-negative infections, $29.9 \pm 8.3$ in gram-positive infections, with $\mathrm{p}=0.04$.

Conclusions: Serum MyD88-independent to MyD88-independentcytokine ratios significantly discriminated gram-negative from gram-positive pneumonia. As technology improves our ability to generate panels of cytokines quickly from clinical specimens, a strategy of pooled cytokine ratios, based on underlying pathophysiology, as was done in our study, could guide clinicians in critical early antibiotic choices.
\end{abstract}

Keywords: Pneumonia, cytokines, tumor necrosis factor-alpha, interferon-beta, interleukin-8, gramnegative, gram-positive, innate immunity

\section{Introduction}

The lung is physiologically in contact with the outside world during each breath; humans inhale up to one million bacteria per day in some environments, providing the source for the majority of pulmonary infections [1]. The respiratory tract employs a variety of defense mechanisms to maintain sterility in lung parenchyma. These include upper airway filtering of inspired air, coughing, mucous and mucociliary clearance, barrier protection by airway epithelial surfaces,adaptive immunity, and the innate immune system.

The innate immune system includes cell surface receptors that function as pattern recognition receptors (PRRs). PRRs recognize pathogen-associated molecular patterns (PAMPs) or danger-associated molecular patterns (DAMPs) to initiate immune responses [2]. Examples of PRRs include NOD-like receptors (NLRs), RIG-I-like receptors (RLRs), and the toll-like receptors

(c) 2014 Cowan et al; licensee Herbert Publications Ltd. This is an Open Access article distributed under the terms of Creative Commons Attribution License (http://creativecommons.org/licenses/by/3.0). This permits unrestricted use, distribution, and reproduction in any medium, provided the original work is properly cited. 
Campbell et al. Research Journal of Infectious Diseases 2014,

(TLRs) [3]. The TLRs are a group of 10 type I transmembrane receptors, initially described in Drosophila melanogaster, that function as PRR's [4]. They are expressed on airway epithelial cells [5] and antigen-presenting cells [6]. Individual TLRs differ in their ligand specificity; TLR4 is known to bind gram-negative bacterial lipopolysaccharide (LPS), various heat shock proteins, Lipid A, paclitaxol, and the respiratory syncytial virus F protein [7]. TLR2 binds gram-positive bacterial molecules such as lipoteichoic acid (LTA), lipoproteins, mycobacteria cell-wall lipoarabinomannan [7], and the atypical LPS found in Liptosipra and Porphyromonas species [8].

TLR2 and TLR4 signaling have been investigated in a variety of models $[9,10]$. All TLRs except TLR3 can transduce receptor-ligand binding events by activation of intracellular myeloid differentiation factor 88 (MyD88) [11]. Downstream of MyD88, IL-1R-associated kinase (IRAK) and TNF-receptorassociated factor 6 (TRAF6) [12] activate TAK1 and MAP kinase kinase 6 (MKK6), which in turn activate NF-kB, JNK, and p38 [13]. NF-kB is a critical regulator of IL-8 [14,15], and MyD88 knockout mice do not produce TNF-a, IL-1 $\beta$, or IL-6. MyD88 knockouts do not manifest endotoxic shock in response to LPS, indicating that this pathway is essential for the biological response to this signal [16].

TLR4 can also transduce signal via a MyD88-independent pathway. Ligand receptor interaction results in association with TRIF and TRAM, leading to activation of interferon-regulatory factor 3 (IRF3) [17], inducing IFN- $\beta[3,18]$ and RANTES $[19,20]$ production. These mediators are not produced upon stimulation of the MyD88-dependant pathway and are not blocked by the MyD88 pathway inhibitor TGF- $\beta$ [21]. In murine Pseudomonas aeurginosa pneumonia, MyD88 knockout mice do not up-regulate TNF-a [22]. In contrast, MyD88 knockout mice retain the ability to produce RANTES with TLR stimulation [23], and MyD88 knockout bone marrow derived cells retain the ability to make IFN- $\beta$ [24].

Knapp et.al. investigated the role of TLR2 in murine pneumococcal pneumonia. TLR2 expression in murine lung tissue was found to increase following inoculation with S. pneumoniae in wild type mice. Alveolar macrophages from wild type mice inoculated with S.pneumoniae produced significantly higher amounts of TNF- $a$ and KC than TLR2 knockout mice, indicating that TLR2 is important in the macrophage response to pneumococcus [25]. Additionally, S. pneumoniae induced TLR2 mRNA expression, IL-8 expression, and NF-kB activity in HRK-293 cells [15].

TLR4 deficient mice have reduced survival and increased lung bacterial burden as compared to wild type mice in experimental Klebisella pneumoniae [26]. Non-typeable Haemophilus influenzae is known to have both the TLR4 ligand LPS, as well as several lipoproteins which are TLR2 ligands. In mouse models of pneumonia with this pathogen TLR4 but not TLR2 was shown to be important for early cytokine and chemokine production, suggesting that TLR4 pathways are important in the innate immune defense of this particular gram-negative pathogen [27]. In murine models of Acinetobacter baumanni pneumonia, TLR4 knockout mice were found to have higher bacterial loads, impaired cytokine and chemokine response, and delayed lung inflammation as compared to wild type controls [28]. These studies support a key role for TLR4 in the response to gram-negative pneumonia.

Given the differential roles of TLR2 and TLR4 in gram-negative vs. gram-positive infections, we reasoned that the differential downstream cytokine production from the MyD88-in-dependent (IFN- $\beta$ and RANTES) and MyD88-dependent (IL-8 and TFN- $\alpha$ ) could be used in a rapid assay to distinguish these pneumonias. Further, as there is typically wide variability in individual cytokine levels in patients, we hypothesized that the ratio ([IFN- $\beta]$ X[RANTES]/[IL-8]X[TNF- $\alpha]$ ) might be a better indicator of pneumonia type than individual cytokine levels. We sought to test this in patients with severe pneumonia at the University of Maryland.

\section{Materials and methods Study design and measurements}

A portion of the patients enrolled in this study were enrolled under protocol $\mathrm{H}-23204$, while the later patients (2010 and beyond) were enrolled under protocol HP-00043013, both approved by the University of Maryland IRB. Included were adults 18 years of age and older admitted to the University of Maryland Medical Intensive Care Unit (MICU) with an admission diagnosis of severe pneumonia (community- or hospitalacquired). Candidate patients were identified as soon as possible after admission by daily review of recent admissions with the MICU attending physician. Candidate patients were enrolled after giving informed consent, most commonly by the patient's durable power-of-attorney. Exclusion criteria were: Chronic ventilation or presence of a tracheostomy, severe immunosuppression (AIDS, metastatic cancer, neutropenia), active tuberculosis, hematocrit less than $20 \%$, PT-INR $>3.0$, platelets $<20 \mathrm{k} / \mathrm{mm}^{3}$, inability to obtain informed consent, or denied permission by the patients clinical physician.

Data collected on each enrolled patient were: Apache II score in the first 24 hours after presentation, age, sex, race, maximum temperature in first 24 hours of admission, and all culture results. A culture was considered positive if it was from a respiratory, pleural, or blood source, and was specifically treated with antibiotics by the clinical physician. Positive cultures were recorded as gram-negative or gram-positive on microbiologic characterization of the organism in the culture. A third group included patients where no organism was definitively identified, or other organisms were causative (fungal, mycobacterial, or viral).

Each patient had one serum sample taken as close to the time of admission as possible, typically within 12 hours and universally within 24 hours. Serum was frozen at $-80^{\circ} \mathrm{C}$ until assayed in the University of Maryland Cytokine Core Facility for IL-8, TNF- $a$, and RANTES (www.cytokines.com). IFN- $\beta$ was measured using a commercially available (PBL Biomedical 
Laboratories, Piscatawy, NJ) sandwich ELISA kit using standard company protocol.

\section{Data analysis}

Baseline characteristics for enrolled patients were tabulated for all variables measured. Groups were compared using paired t-test assuming unequal variance for continuous variables. Pearson chi-square was used for categorical data. Individual cytokine levels were compared between groups. Additionally, a composite continuous variable (ratio) was calculated for each subject, and was calculated as the product of IFN- $\beta$ and RANTES levels, divided by the product of IL-8 and TNF- $a$ levels. Cytokine and ratio levels were compared between groups by t-test assuming unequal variance.

\section{Results}

Dataset

Two patients initially enrolled were dropped from the study. One patient was an intravenous drug user who did not have a central line, making a blood draw impossible. The second patient's sample was mislabeled in a bin with blood from other patients, and could not be unambiguously identified. Both of these patients were excluded from the analysis. Therefore, 53 patients were enrolled in and completed the study between January, 2006 and September, 2013. Demographics on each analyzed subject are shown in Table 1. There were 20 (38\%) whites, $30(57 \%)$ blacks and $3(5 \%)$ other who averaged $58.8 \pm$ 18 years of age. $28(53 \%)$ of the subjects were male, and the overall group had an average Apache II score of 21.9 $\pm 7.1 . \mathrm{T}_{\max }$ averaged $100.7 \pm 1.9$. There were no significant differences between the gram-positive and the gram-negative groups in any demographic.

Table 2 shows culture results by organism, source, and gram stain type for each subject. There were $14 \mathrm{gram}$-negative, 17 gram-positive, and 22 gram-unknown/other infections.

Cytokine levels for patient serum samples are tabulated in Table 3, and shown graphically in Figure 1. None of the cytokines measured demonstrated a statistically significant

Table 1. Clinical Characteristics of enrolled patients.

\begin{tabular}{llllllllllllllll}
\hline & \multicolumn{3}{c}{ ALL } & \multicolumn{3}{c}{ Gram (-) } & \multicolumn{3}{c}{ Gram (+) } & \multicolumn{3}{c}{ Unknown } & P $^{* *}$ \\
\hline & N & Mean & STD & N & Mean & SEM & N & Mean & SEM & N & Mean & SEM & \\
\hline Age & 53 & 58.8 & 18 & 14 & 56.9 & 5.4 & 17 & 56.1 & 4.4 & 22 & 62.0 & 3.5 & 0.91 \\
Apache II & 53 & 21.9 & 7.1 & 14 & 24.8 & 1.5 & 17 & 23.5 & 1.6 & 22 & 18.8 & 1.6 & 0.56 \\
$\mathrm{~T}_{\max }$ within 24 hrs. of admission & 53 & 100.7 & 1.9 & 14 & 101.1 & 0.6 & 17 & 101.1 & 0.4 & 22 & 100.1 & 0.4 & 0.97 \\
& -- & F & M & -- & F & M & -- & F & M & -- & F & M & -- \\
Gender & 53 & 25 & 28 & 14 & 5 & 9 & 17 & 6 & 11 & 22 & 14 & 8 & 0.99 \\
& -- & Black & White & -- & Black & White & -- & Black & White & -- & Black & White & -- \\
Ethnicity $^{*}$ & 50 & 30 & 20 & 11 & 7 & 4 & 17 & 8 & 9 & 22 & 15 & 7 & 0.86 \\
\hline
\end{tabular}

*There were 2 asians and 1 hispanic not included above.

${ }^{* *} \mathrm{P}$ values calculated by type t-test for all continuous variables. For categorical variables,

$\mathrm{P}$ values are by Pearson Chi-square. All $\mathrm{p}$ values compare gram-negative vs. gram-positive groups.

Table 2. Etiologic organism, site of positive culture, and gram classification of each subject.

\begin{tabular}{llll}
\hline Subject & Pathogen & Source $^{*}$ & Gram type \\
\hline 1 & Enterococcus sp. & Sputum & + \\
2 & S. pneumonia & Blood & + \\
3 & None & None & 0 \\
4 & None & None & 0 \\
5 & P. aeruginosa & Blood, sputum & - \\
6 & None & None & 0 \\
7 & MRSA & Sputum & + \\
8 & MRSA & BAL & + \\
9 & None & None & 0 \\
10 & Streptococcus sp., Viridans & Pleural & + \\
11 & P. aeruginosa & Sputum & - \\
12 & None & None & 0 \\
13 & E. Coli & Blood & - \\
14 & K. pneumonia, S. maltophilia & BAL & - \\
15 & Streptococcus sp., a-hemolytic & BAL & + \\
\hline
\end{tabular}


Campbell et al. Research Journal of Infectious Diseases 2014,

http://www.hoajonline.com/journals/pdf/2052-5958-2-6.pdf

doi: $10.7243 / 2052-5958-2-6$

\begin{tabular}{|c|c|c|c|}
\hline Subject & Pathogen & Source & Gram type \\
\hline 16 & MSSA & BAL & + \\
\hline 17 & None & None & 0 \\
\hline 18 & None & None & 0 \\
\hline 19 & C. koseri & BAL & - \\
\hline 20 & S. maltophila, A. baumannii & Sputum & - \\
\hline 21 & None & None & 0 \\
\hline 22 & Klebsiella pneumonia & Catheter tip & - \\
\hline 23 & None & None & 0 \\
\hline 24 & None & None & 0 \\
\hline 25 & S. pneumonia & Sputum & + \\
\hline 26 & L. pneumophila & BAL (DFA) & - \\
\hline 27 & None & None & 0 \\
\hline 28 & Candida albicans & Blood & 0 \\
\hline 29 & None & None & 0 \\
\hline 30 & MSSA/sputum & Sputum & + \\
\hline 31 & None & None & 0 \\
\hline 32 & MSSA & Blood & + \\
\hline 33 & Streptococcus sp., group G & Sputum & + \\
\hline 34 & P. aeruginosa & Sputum & - \\
\hline 35 & MRSA & Sputum & + \\
\hline 36 & MTB & Sputum & 0 \\
\hline 37 & None & None & 0 \\
\hline 38 & None & None & 0 \\
\hline 39 & MRSA & Blood & + \\
\hline 40 & P. mirabilis & Blood & - \\
\hline 41 & None & None & 0 \\
\hline 42 & Streptococcus sp., group F & Sputum & + \\
\hline 43 & VRE & VRE/blood & + \\
\hline 44 & None & None & 0 \\
\hline 45 & None & None & 0 \\
\hline 46 & K. pneumonia & $\mathrm{BAL}$ & - \\
\hline 47 & P. aeruginosa & Blood & - \\
\hline 48 & None & None & 0 \\
\hline 49 & P. aeruginosa & BAL & - \\
\hline 50 & None & None & 0 \\
\hline 51 & MRSA & Pleural & + \\
\hline 52 & E. Coli, P. mirabilis & BAL & - \\
\hline 53 & S. pneumonia & Sputum & + \\
\hline
\end{tabular}

${ }^{\star}$ BAL: Bronchoalveolar lavage culture; MRSA: Methicillin-resistant $S$. Aureus

MSSA: Methicillin-sensitive S. Aureus; VRE: Vancomycin-resistant Enterococcus sp.

DFA: Fluorescent antibody test

Table 3. Summary of mean admission levels* of MyD88-dependent (IL-8, TNF- $\alpha$ ) and MyD88-independent (RANTES, IFN- $\beta$ cytokines and the ratio. These data are shown graphically in Figure 1.

\begin{tabular}{|c|c|c|c|c|c|c|c|}
\hline & $\begin{array}{l}\text { Gram-unknown } \\
\text { mean }\end{array}$ & $\begin{array}{l}\text { Gram-unknown } \\
\text { SEM }\end{array}$ & $\begin{array}{l}\text { Gram-negative } \\
\text { mean }\end{array}$ & $\begin{array}{l}\text { Gram-negative } \\
\text { SEM }\end{array}$ & $\begin{array}{l}\text { Gram-positive } \\
\text { mean }\end{array}$ & $\begin{array}{l}\text { Gram-positive } \\
\text { SEM }\end{array}$ & ${ }^{* * \text { P-value }}$ \\
\hline IFN- $\beta$ & 260.4 & 23.5 & 319.3 & 25.3 & 239.5 & 37.8 & 0.09 \\
\hline RANTES & 2007.3 & 144.2 & 2229.5 & 268.6 & 1641.0 & 110.9 & 0.06 \\
\hline IL-8 & 153.1 & 41.7 & 184.3 & 58.2 & 235.0 & 52.5 & 0.52 \\
\hline TNF- $\alpha$ & 5.1 & 0.6 & 4.8 & 1.4 & 7.4 & 0.7 & 0.11 \\
\hline Ratio $^{\star * *}$ & 102.8 & 29 & 111.1 & 34.9 & 29.9 & 8.3 & 0.04 \\
\hline
\end{tabular}

${ }^{*}$ All values are $\mathrm{pg} / \mathrm{mL}$ of serum (except Ratio values, which is unitless). ${ }^{* *} \mathrm{P}$ values calculated by $\mathrm{t}$-test (unequal variance).

${ }^{* * *}$ Calculated as [IFN- $\left.\beta\right]$ X[RANTES]/[IL-8]X[TNF- $\left.\alpha\right]$. 


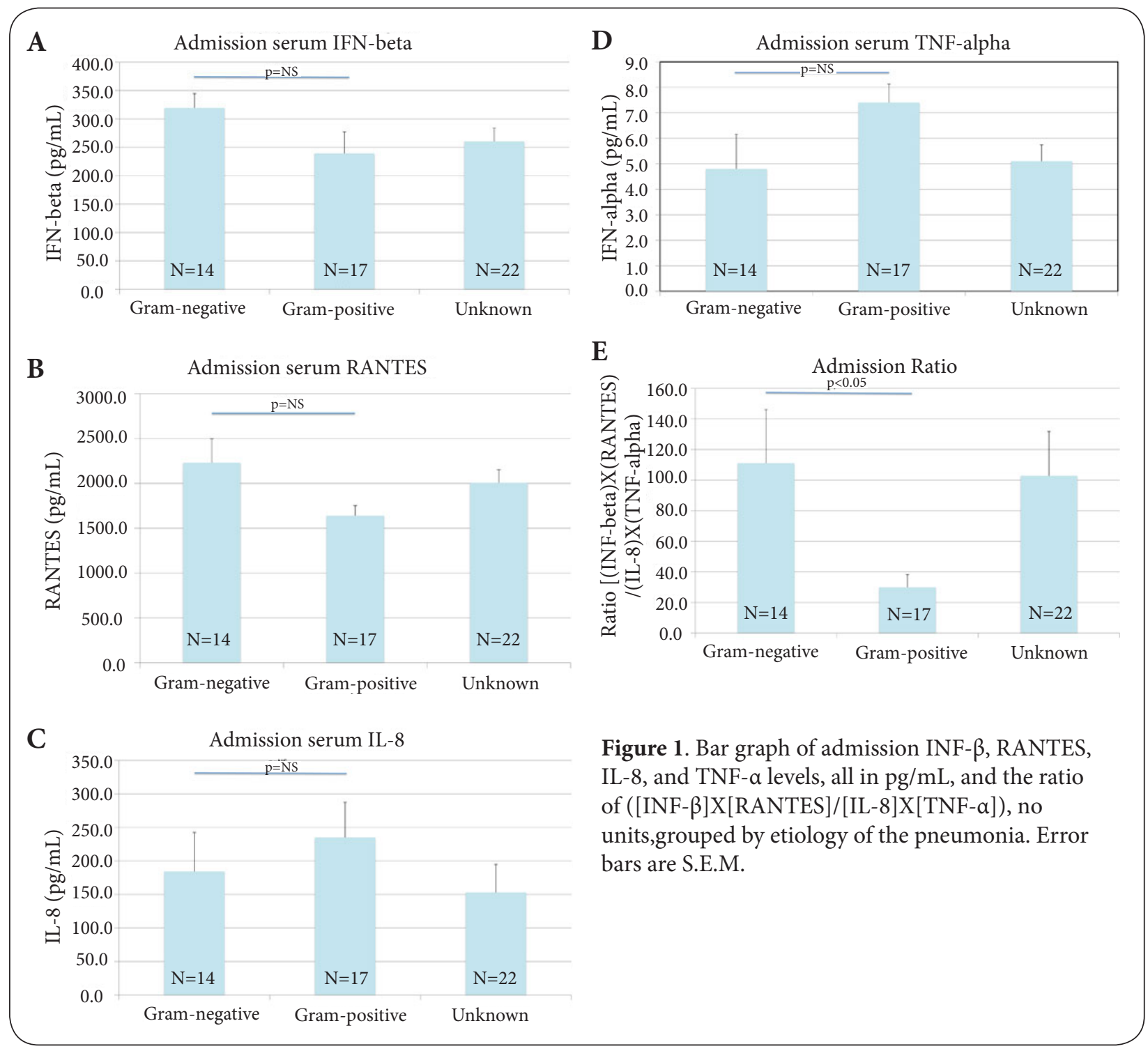

difference between the gram-negative and the gram-positive groups. However, the ratio of MyD88-independent cytokines to MyD88-dependent cytokines [IFN- $\beta$ ] X [RANTES]/[IL-8] X [TNF- $\alpha$ ] demonstrated a significant difference between the groups, $111.1 \pm 4.9$ for gram-negative vs. $29.9 \pm 8.3$ for grampositive, with a $p$ value of 0.04 .

\section{Discussion}

Few studies have been able to use cytokine levels as a clinically useful tools in infectious diseases. One study looking at IL-1 $\beta$, IL-10, and IL-8 in 47 patients with pneumonia was able to discriminate $K$. pneumoniae infection based on cytokine levels [29]. However, IL-6, IL-8, and CRP levels were unable to distinguish varied pathogens in 87 cases of childhood pneumonia [30]. Variability in TLR activation and subsequent cytokine production with different infectious diseases has made the clinical use of cytokine measurement complex and problematic.

TLR2 has been shown to bind to multiple ligands, including the lipoteichoic acid (LTA) found in gram-positive bacteria, but also glycolipids, lipopeptides, and lipoproteins [31]. Though gram-negative bacteria are thought to primarily activate TLR4 with LPS, TLR2 receptors can also be activated by other gram-negative bacterial products. Infection with $P$. aeruginosa can have paradoxical effects on IL-8 and RANTES levels. The organism is known to increase IL-8 levels in human airway epithelial cells by secreting small molecular weight factors [32]. However, RANTES is degraded by the metalloproteases, alkaline protease, and elastase secreted by P. aeruginosa infecting airway epithelial cells, whereas IL-8 is much more resistant to proteolysis [33]. In human neutrophils, TLR2 and TLR4 mediated production of IL-8 was shown to be initially 
induced directly by leipoteichoic acid, but with larger scale production coming from a second phase mediated by endogenous TNF- $a$ [34]. The majority of LTA-induced neutrophil activation was independent of the TLR2 and TLR4-mediated pathways, but relied on CD14. Levels of IL-8 were able to be attenuated by IL-10 in the second phase, likely due to its regulatory effect on TNF-a. These data suggest that cytokine levels in various infections change markedly over the course of infection, and have multiple mechanisms responsible for their production.

In vivo data from real human infections is even more variable. A recent study measuring TLR2 and TLR4 expression in elderly patients with high mortality infections found that expression of both TLRs were decreased in patients who died compared to survivors [35]. TLR2 and TLR4 expressions were positively correlated with IL-1, IL-6, and TNF-a levels, but had no correlation with CRP, APACHE II score or CURB-65 score. Furthermore, a prospective study of 1,895 patients of hospitalized with CAP and sepsis published in 2013 showed that among 423 small molecules detected in serum in the emergency department, the levels of 70 of those differed significantly between survivors and non-survivors, and two major molecules stimulated increased TNF- $\alpha$ and IL-1 $\beta$. Despite these results, a metabolite-based prognostic model to predict 90 day mortality performed only modestly (AUC $=0.67$, 95\% Cl 0.48-0.81) [36].

Given such variation in individual cytokine levels in infectious diseases, we demonstrated that a composite index of TLR2 to TLR4 related cytokines functioned much better to discriminate the clinically important question of whether the causative organism is gram-positive or gram-negative. As technology for measurement of cytokine levels improves, the use of fast, point-of-care analysis of cytokine ratios could significantly aid in the management of these difficult and sick patients.

\section{Conclusion}

The statistically higher ratio of MyD88-independent to MyD88-dependent cytokine levels in patients with culture proven gram-negative vs. gram-positive infection supports our original hypothesis. A ratio of cytokines, designed utilizing known pathophysiologic pathways, was a much more robust discriminator of infection type than individual cytokine levels, might have important early clinical decision implications in the care of patients with severe pneumonia.

\section{Limitations}

A significant number of patients enrolled in this study did not have a positive culture result, and their exclusion from the analysis of gram-negative vs. gram-positive cytokines may have skewed our results. However, in the majority of common clinical infectious diseases, no etiologic agent is identified by culture, and nothing can be done to account for any bias that may be introduced by this clinical limitation.
This study was performed as a proof-of-principle investigation. An increased number of cytokine and other inflammatory mediators, with a broad statistical approach to combining the measurements could result in even better performance, and may even allow determination of specific infectious species. Multiplexed strategies for the analysis of clinical specimens could significantly increase the utility of this strategy.

\section{Competing interests}

The authors declare that they have no competing interests.

\section{Authors' contributions}

\begin{tabular}{|l|c|c|}
\hline Authors' contributions & DC & MJC \\
\hline Research concept and design & -- & $\checkmark$ \\
\hline Collection and/or assembly of data & -- & $\checkmark$ \\
\hline Data analysis and interpretation & $\checkmark$ & $\checkmark$ \\
\hline Writing the article & $\checkmark$ & $\checkmark$ \\
\hline Critical revision of the article & $\checkmark$ & $\checkmark$ \\
\hline Final approval of article & $\checkmark$ & $\checkmark$ \\
\hline Statistical analysis & $\checkmark$ & $\checkmark$ \\
\hline
\end{tabular}

\section{Publication history}

Editors: Gyanendra Singh, LSU Health Sciences Center, USA. Vinod Singh, Barkatullah University, India.

Senior Editor: Isaac Karimi, Razi University, Iran.

EIC: Ishtiaq Qadri, King Abdul Aziz University, Saudi Arabia.

Received: 05-Jul-2014 Final Revised: 03-Nov-2014

Accepted: 11-Nov-2014 Published: 18-Nov-2014

\section{References}

1. Wijkstrom-Frei C, El-Chemaly S, Ali-Rachedi R, Gerson C, Cobas MA Forteza R, Salathe $\mathrm{M}$ and Conner GE. Lactoperoxidase and human airway host defense. Am J Respir Cell Mol Biol. 2003; 29:206-12. | Article | PubMed

2. Medzhitov R. Toll-like receptors and innate immunity. Nat Rev Immunol. 2001; 1:135-45. | Article | PubMed

3. Juang YT, Lowther W, Kellum M, Au WC, Lin R, Hiscott J and Pitha PM. Primary activation of interferon $A$ and interferon $B$ gene transcription by interferon regulatory factor 3. Proc Natl Acad Sci U S A. 1998; 95:9837-42. | Article | PubMed Abstract | PubMed Full Text

4. Belvin MP and Anderson KV. A conserved signaling pathway: the Drosophila toll-dorsal pathway. Annu Rev Cell Dev Biol. 1996; 12:393416. | Article | PubMed

5. Greene CM and McElvaney NG. Toll-like receptor expression and function in airway epithelial cells. Arch Immunol Ther Exp (Warsz). 2005; 53:418-27. | Pdf | PubMed

6. Iwasaki A and Medzhitov R. Toll-like receptor control of the adaptive immune responses. Nat Immunol. 2004; 5:987-95. | Article | PubMed

7. Heldwein KA, Liang MD, Andresen TK, Thomas KE, Marty AM, Cuesta N, Vogel SN and Fenton MJ. TLR2 and TLR4 serve distinct roles in the host immune response against Mycobacterium bovis BCG. J Leukoc Biol. 2003; 74:277-86. | Article | PubMed

8. Hirschfeld M, Weis JJ, Toshchakov V, Salkowski CA, Cody MJ, Ward DC Qureshi N, Michalek SM and Vogel SN. Signaling by toll-like receptor 2 and 4 agonists results in differential gene expression in murine macrophages. Infect Immun. 2001; 69:1477-82. | Article | PubMed Abstract | PubMed Full Text

9. Jones BW, Heldwein KA, Means TK, Saukkonen JJ and Fenton MJ. Differential roles of Toll-like receptors in the elicitation of proinflammatory responses by macrophages. Ann Rheum Dis. 2001; 60 Suppl 3:iii6-12. | Article | PubMed Abstract | PubMed Full Text 
10. Kawai T and Akira S. Toll-like receptor downstream signaling. Arthritis Res Ther. 2005; 7:12-9. | Article | PubMed Abstract | PubMed Full Text

11. Toshchakov V, Jones BW, Perera PY, Thomas K, Cody MJ, Zhang S, Williams BR, Major J, Hamilton TA, Fenton MJ and Vogel SN. TLR4, but not TLR2, mediates IFN-beta-induced STAT1alpha/beta-dependent gene expression in macrophages. Nat Immunol. 2002; 3:392-8. | Article | PubMed

12. Cao Z, Xiong J, Takeuchi M, Kurama T and Goeddel DV. TRAF6 is a signal transducer for interleukin-1. Nature. 1996; 383:443-6. | Article | PubMed

13. Wang C, Deng L, Hong M, Akkaraju GR, Inoue J and Chen ZJ. TAK1 is a ubiquitin-dependent kinase of MKK and IKK. Nature. 2001; 412:346-51. | Article | PubMed

14. Mukaida N, Mahe $\mathrm{Y}$ and Matsushima K. Cooperative interaction of nuclear factor-kappa B- and cis-regulatory enhancer binding proteinlike factor binding elements in activating the interleukin- 8 gene by pro-inflammatory cytokines. J Biol Chem. 1990; 265:21128-33. | Article I PubMed

15. Schmeck B, Huber S, Moog K, Zahlten J, Hocke AC, Opitz B, Hammerschmidt S, Mitchell TJ, Kracht M, Rosseau S, Suttorp N and Hippenstiel S. Pneumococci induced TLR- and Rac1-dependent NFkappaB-recruitment to the IL-8 promoter in lung epithelial cells. Am J Physiol Lung Cell Mol Physiol. 2006; 290:L730-L737. | Article I PubMed

16. Kawai T, Adachi O, Ogawa T, Takeda K and Akira S. Unresponsiveness of MyD88-deficient mice to endotoxin. Immunity. 1999; 11:115-22. | Article | PubMed

17. Fitzgerald KA, Rowe DC, Barnes BJ, Caffrey DR, Visintin A, Latz E, Monks $B$, Pitha PM and Golenbock DT. LPS-TLR4 signaling to IRF-3/7 and NFkappaB involves the toll adapters TRAM and TRIF. J Exp Med. 2003; 198:1043-55. | Article | PubMed Abstract | PubMed Full Text

18. Hiscott J, Pitha P, Genin P, Nguyen H, Heylbroeck C, Mamane Y, Algarte $M$ and Lin R. Triggering the interferon response: the role of IRF-3 transcription factor. J Interferon Cytokine Res. 1999; 19:1-13. | Article | PubMed

19. Lin R, Heylbroeck C, Genin P, Pitha PM and Hiscott J. Essential role of interferon regulatory factor 3 in direct activation of RANTES chemokine transcription. Mol Cell Biol. 1999; 19:959-66. | Article | PubMed Abstract | PubMed Full Text

20. Genin P, Algarte M, Roof P, Lin R and Hiscott J. Regulation of RANTES chemokine gene expression requires cooperativity between NF-kappa B and IFN-regulatory factor transcription factors. J Immunol. 2000; 164:5352-61. | Article | PubMed

21. Naiki Y, Michelsen KS, Zhang W, Chen S, Doherty TM and Arditi M. Transforming growth factor-beta differentially inhibits MyD88dependent, but not TRAM- and TRIF-dependent, lipopolysaccharideinduced TLR4 signaling. J Biol Chem. 2005; 280:5491-5. | Article | PubMed

22. Skerrett SJ, Liggitt HD, Hajjar AM, Ernst RK, Miller SI and Wilson CB. Respiratory epithelial cells regulate lung inflammation in response to inhaled endotoxin. Am J Physiol Lung Cell Mol Physiol. 2004; 287:L14352. | Article | PubMed

23. Behera AK, Hildebrand E, Bronson RT, Perides G, Uematsu S, Akira S and Hu LT. MyD88 deficiency results in tissue-specific changes in cytokine induction and inflammation in interleukin-18-independent mice infected with Borrelia burgdorferi. Infect Immun. 2006; 74:1462-70. | Article | PubMed Abstract | PubMed Full Text

24. Hoshino K, Kaisho T, Iwabe T, Takeuchi O and Akira S. Differential involvement of IFN-beta in Toll-like receptor-stimulated dendritic cell activation. Int Immunol. 2002; 14:1225-31. | Article | PubMed

25. Knapp S, Wieland CW, van 't Veer C, Takeuchi O, Akira S, Florquin S and van der Poll T. Toll-like receptor $\mathbf{2}$ plays a role in the early inflammatory response to murine pneumococcal pneumonia but does not contribute to antibacterial defense. J Immunol. 2004; 172:3132-8. | Article | PubMed

26. Schurr JR, Young E, Byrne P, Steele C, Shellito JE and Kolls JK. Central role of toll-like receptor 4 signaling and host defense in experimental pneumonia caused by Gram-negative bacteria. Infect Immun. 2005 ;
73:532-45. | Article | PubMed Abstract | PubMed Full Text

27. Wieland CW, Florquin S, Maris NA, Hoebe K, Beutler B, Takeda K, Akira $S$ and van der Poll T. The MyD88-dependent, but not the MyD88independent, pathway of TLR4 signaling is important in clearing nontypeable haemophilus influenzae from the mouse lung. J Immunol. 2005; 175:6042-9. | Article | PubMed

28. Knapp S, Wieland CW, Florquin S, Pantophlet R, Dijkshoorn L, Tshimbalanga N, Akira S and van der Poll T. Differential roles of CD14 and toll-like receptors $\mathbf{4}$ and $\mathbf{2}$ in murine Acinetobacter pneumonia. Am J Respir Crit Care Med. 2006; 173:122-9. | Article | PubMed

29. Wu CL, Chan MC, Chang GC, Lee YL, Chin CS, Chang KM and Hsu JY. Etiology and cytokine expression in patients requiring mechanical ventilation due to severe community-acquired pneumonia. J Formos Med Assoc. 2006; 105:49-55. | Article I PubMed

30. Tumgor G, Celik U, Alabaz D, Cetiner S, Yaman A, Yildizdas D and Alhan E. Aetiological agents, interleukin-6, interleukin-8 and CRP concentrations in children with community- and hospital-acquired pneumonia. Ann Trop Paediatr. 2006; 26:285-91. | Article | PubMed

31. Aderem A and Ulevitch RJ. Toll-like receptors in the induction of the innate immune response. Nature. 2000; 406:782-7. | Article I PubMed

32. Leidal KG, Munson KL and Denning GM. Small molecular weight secretory factors from Pseudomonas aeruginosa have opposite effects on IL-8 and RANTES expression by human airway epithelial cells. Am J Respir Cell Mol Biol. 2001; 25:186-95. I Article I PubMed

33. Leidal KG, Munson KL, Johnson MC and Denning GM. Metalloproteases from Pseudomonas aeruginosa degrade human RANTES, MCP-1, and ENA-78. J Interferon Cytokine Res. 2003; 23:307-18. | Article | PubMed

34. Hattar K, Grandel U, Moeller A, Fink L, Iglhaut J, Hartung T, Morath S, Seeger W, Grimminger F and Sibelius U. Lipoteichoic acid (LTA) from Staphylococcus aureus stimulates human neutrophil cytokine release by a CD14-dependent, Toll-like-receptor-independent mechanism: Autocrine role of tumor necrosis factor-[alpha] in mediating LTAinduced interleukin-8 generation. Crit Care Med. 2006; 34:835-41. Article | PubMed

35. Tang L, Li Q, Bai J, Zhang H, Lu Y and Ma S. Severe pneumonia mortality in elderly patients is associated with downregulation of Toll-like receptors 2 and 4 on monocytes. Am J Med Sci. 2014; 347:34-41. | Article | PubMed

36. Seymour CW, Yende S, Scott MJ, Pribis J, Mohney RP, Bell LN, Chen YF, Zuckerbraun BS, Bigbee WL, Yealy DM, Weissfeld L, Kellum JA and Angus DC. Metabolomics in pneumonia and sepsis: an analysis of the GenIMS cohort study. Intensive Care Med. 2013; 39:1423-34. | Article | PubMed Abstract | PubMed Full Text

\section{Citation}

Campbell D and Cowan MJ. Differential systemic MyD88-dependent versus MyD88- independent cytokine ratio by etiologic agent in adults with severe community-acquired pneumonia. Res $J$ Infect Dis. 2014; 2:6. http://dx.doi.org/10.7243/2052-5958-2-6 